\title{
Gazette
}

\section{APSA Awards Presented at 1997 Annual Meeting}

\section{DISSERTATION AWARDS}

Gabriel Almond Award (\$500)

For the best doctoral dissertation completed and accepted in 1996 or 1997 in the field of comparative politics.

Award Committee: Dorothy Stetson, Florida Atlantic University, chair; Evelyn Huber, University of North Carolina at Chapel Hill; and Susanne Hoeber Rudolph, University of Chicago

Recipient: Mitchell Orenstein, Brown University

Dissertation: "Out of the Red; Building Capitalism and Democracy in PostCommunist Europe"

Dissertation Chair: David L. Cameron, Yale University

This dissertation addresses a topic of great interest in comparative politics: the feasibility and political effects of economic liberalization in newly installed democratic regimes. Orenstein focuses on the cases of Poland and the Czech Republic, presenting a detailed comparison of initial strategies for transformation and documenting the profoundly different political effects. While shock therapy led to a startling backlash against reform among the Polish people, the Czech social-liberal policies earned popular support. Detailed studies of policies in areas of privatization, unemployment and labor policy, and social policy shows that Czech leaders made conscious efforts to build political support for needed transitional steps toward market reforms, while Polish leaders took a more technocratic, less sensitive, approach. This dissertation shows clearly and persuasively that the differential success of economic reform programs rests on differential capacities to distribute the costs of reform equitably. It becomes part of an expanding literature that challenges the way in which excessive economism of multilateral lending institutions and liberal consultants fails to recognize the role of political calculations in the reform process.

Mitchell Orenstein's analysis makes a significant contribution by taking a comprehensive view, including both political institution-building and economic and social policymaking. The two cases are well-chosen, the field work is rich, and the comparative analysis is systematic and careful. The analysis and conclusions forcefully challenge the neoliberal view that radical state withdrawal and economic shock therapy are the best strategies for building strong market economies and consolidating democracies. Given the strong influence that the neoliberal view has had not only on policymaking but also on the discussion in social science, this challenge is an important contribution to the field of comparative politics.

\section{William Anderson Award (\$500)}

For the best doctoral dissertation completed and accepted in 1996 or 1997 in the field of state and local politics, federalism, or intergovernmental relations.

Award Committee: Daniel Elazar, Temple University, chair; James McDavid, University of Victoria; and Nelson Wikstrom, Virginia Commonwealth University

Recipient: Dale Mason, University of New Mexico-Gallop

Dissertation: "Interest Group Federalism: Indian Gaming and the Status of Indian Tribes in the American Political System"

Dissertation Chair: Allen Hertzke, University of Oklahoma

The William Anderson Award is presented annually for the best doctoral dissertation in the fields of federalism, intergovernmental relations and state and local politics. Each dissertation considered for this award has already been nominated by respective departments and each one has outstanding merits.

One dissertation stands out among those nominated in 1997. W. Dale Mason, who received his doctorate in Political Science from the University of Oklahoma, is this year's winner of the William Anderson Award.

His dissertation, Interest Group Federalism: Indian Gaming and the Status of Indian Tribes in the American Political System, combines broad historical and legal analysis with detailed case studies of gaming-related political and legal decisions in New Mexico and Oklahoma to produce a dissertation that is thoroughly documented and a pleasure to read.

Dr. Mason has captured the unique status of American Indian tribes in the American federal system at the end of this century. Gaming, because it generates revenue and conflicts with state governments has become the focus of key legal and political struggles. Dr. Mason has made a major contribution to our understanding of Indian sovereignty, its exercise in practice, and the system of federal-state-tribe relations it is generating to accommodate the new realities of Indian self determination.

\section{Edward S. Corwin Award (\$500)}

For the best doctoral dissertation completed and accepted in 1996 or 1997 in the field of public law.

Award Committee: Judith Baer, Texas A\&M University, chair; Leslie F. Goldstein, University of Delaware; and Michael E. Libonati, Temple University Law School

Recipient: Thomas F. Burke, Wellesley College

Dissertation: "Litigation and its Discontents: The Politics of Adversarial Legalism"

Dissertation Chair: Robert Kagan, University of California, Berkeley

This dissertation is a policy study which seeks to understand and explain the political roots of litigiousness in the United States. To this end, Professor Burke analyzes two efforts at policy reform aimed at reducing litigation, one which succeed and one which failed, and the adoption of one policy reform which increased litigation. These were, respectively, the defeat of no-fault auto insurance in California, the adoption of a federal vaccine injury compensation program, and the enactment of the Americans with Disabilities Act (ADA). This well-written, perspicuous, and methodologically sophisticated policy analysis focuses directly on the question of why courts are so central to the American system of justice, a question that has captured Americans' attention from the time of Alexis de Tocqueville right up to the presidential campaign of George Bush. The dissertation already has the tone and polish of a completed book. 


\section{Harold D. Lasswell Award ( $\$ 500)$}

For the best doctoral dissertation completed and accepted in 1996 or 1997 in the field of policy studies.

Award Committee: William A. Diaz, Hubert Humphrey Institute, University of Minnesota, chair; Dianne Pinderhughes, University of Illinois at Urbana-Champaign; and Todd Swanstrom, SUNYAlbany

Recipient: Nancy B. Shulock, California State University, Sacramento

Dissertation: "Interpretive Theory of Policy Analysis"

Dissertation Chair: Stuart Hill, University of California, Davis

Nancy Shulock's dissertation addresses one of the enduring paradoxes of policy analysis: why, despite strong empirical evidence and theoretical argument that policy analysis is not used by policymakers, has our society made a large, and increasing, investment in it? To resolve this paradox, Dr. Shulock utilizes a creative synthesis of "interpretive theory." It tries to capture the complexity of the policy process and the various ways that information is used to support and legitimize the process. The interpretive framework leads to an emphasis on the process of decisionmaking as well as on the outcome. Information fulfills quite a different role in this framework than in one focused exclusively on outcomes and problem solving. She tests this theory against others using a creative and demanding methodology involving a multiple regression analysis of 105 cases of major legislation considered by the House of Representatives from 1985 to 1994.

Her conclusion, briefly stated, is that policy analysis has been defined too narrowly as improving the availability and accuracy of information about policy options and clarifying social goals.

Instead, Shulock finds policy analysis useful because it often serves the alternative goals of defining how policies are publicly framed and legitimized. Interpretative theory predicts that policy analysis's use increases as competition increases because policy analysis provides tools in battles over issue definition and jurisdiction.

Dr. Shulock's dissertation sparkles with originality, and soars above conventional theoretical approaches, all the while explaining and reestablishing the role of policy analysis in the political process.

\section{Helen Dwight Reid Award (\$500)}

For the best doctoral dissertation completed and accepted in 1996 or 1997 in the field of international relations, law, and politics.

Award Committee: Dina Zinnes, University of Illinois at Urbana-Champaign, chair; Bruce Bueno de Mesquita, Stanford University; and Paul K. Huth, University of Michigan

\section{Recipient: Kenneth Schultz, Princeton University}

Dissertation: "Domestic Political Competition and Bargaining in International Crisis"

\section{Dissertation Chair: Stephen Krasner, Stanford University}

When dissertations become a pleasure to read, we know the profession is going in the right direction. Of the thirteen dissertations submitted for the Helen Dwight Reid Award the committee found four that it considered superbly met the criteria of (1) identification of an important problem, (2) significant contribution to our understanding of the issue at a broad theoretical level, (3) development and analysis of the argument to demonstrate its falsifiability, and (4) marshalling of evidence to support the argument in a replicable fashion. The committee wishes to commend, in alphabetical order: Henk Erich Goemans ("The Causes of War Termination: Domestic Politics and War Aims"), Robert C. Orr ("Paradigm Lost? U.S. Approaches to Democracy Promotion in Developing Countries"), and Eric R. Reinhardt ("Posturing Parliaments: Ratifications, Uncertainty, and International Bargaining") for their creative, thoughtful, and significant theoretical contributions to our understanding of international politics.

The committee, nevertheless, judged Kenneth A. Schultz's "Domestic Political Competition and Bargaining in International Crises", to be exceptional and the winner of the Helen Dwight Reid Award. Schultz picks up the gauntlet of the "democratic peace" puzzle and, through an ingenious game-theoretic argument, proposes a new solution. The basic premise is that wars are most likely to occur when the disputants have private information about their willingness and ability to wage war. Thus the open, competitive nature of a democratic government provides a medium for states to credibly reveal their private information and consequently permit both sides to bargain through a conflict and avoid war. The model intriguingly changes the dyadic nature of the "democratic peace" puzzle into a monadic analysis which is well supported by statistical evidence from 2000 disputes between 1815 to 1985. The game-theoretic model is developed and the statistical analysis described with a lucidity seldom found in a doctoral thesis. In short, this dissertation was an exciting and fun read that we recommend to the IR community's bestseller list. We look forward to the author's sequel.

As a small postscript we wish to note that the committee avoided any conflicts of interest. Individuals involved in a given dissertation excused themselves from votes on that dissertation.

\section{E.E. Schattschneider Award (\$250)}

For the best doctoral dissertation completed and accepted in 1996 or 1997 in the field of American government and politics.

Award Committee: Robert J. Spitzer, SUNY-Cortland, chair; Diana Evans, Trinity College; and Trudi Miller, University of Minnesota

Recipient: Gregory J. Wawro, Columbia University

Dissertation: "Legislative Entrepreneurship in the U.S. House of Representatives"

Dissertation Chair: Theodore Lowi, Cornell University

Gregory J. Wawro's dissertation examines the crucial question of why and under what circumstances members of Congress produce innovative, integrative legislation. Wawro's approach to what he labels "legislative entrepreneurship" departs from the conventional analysis which argues that such activity is animated by district-oriented rewards or by conventional logrolling techniques. Wawro finds these explanations inadequate. Focusing on the House of Representatives, Wawro notes that members face two realms that compete for legisiators' attention-the home district, and Washington. In a significant departure from most Congressional analysis, Wawro argues that legislative entrepreneurship is essentially divorced from reelection and other home-district forces because constituents are mostly oblivious to members' legislative activity, and because legislative entrepreneurship is, by its nature, focused on the Washington arena. Campaign finance laws provide a key mechanism linking the goal of reelection with that of producing public policy precisely because campaign finance laws insulate members from cam- 
paign pressures that would otherwise corrode legislative entrepreneurship.

Members of Congress work to provide collective goods, such as bills that combine disparate elements blended to rally majority support, in order to advance through the hierarchy of jobs in the House. Wawro's "jobs ladder" hypothesis shows that direct electoral motivations for legislative entrepreneurship are weak, but that the organizational/advancement motivations within Congress, whether through the committee structure or through party leadership, are strong. Wawro marshals formidable data analysis to support his thesis, including a pair of precisely chosen econometric models. The two-stage probit model used to analyze the direct electoral effects of legislative entrepreneurship is skillfully employed.

In all, Wawro's dissertation combines work of empirical rigor, theoretical elegance, and conceptual import. Compelling case examples and careful presentation make this dissertation a highly worthy recipient of the Schattschneider Award.

Honorable Mention: Laura S. Jensen, University of Massachusetts-Amherst, for her dissertation, "The Entitlement Mentality: American Expectations of the State," completed at the University of Connecticut; dissertation chair Robert S. Gilmour.

\section{Leo Straus Award (\$500)}

For the best doctoral dissertation completed and accepted in 1996 or 1997 in the field of political philosophy.

Award Committee: Joan Tronto, Hunter College, CUNY, chair; Deborah

Baumgold, University of Oregon; and

Richard Dagger, Arizona State

University

Recipient: Andrew Sabl, Williams College

Dissertation: "Political Offices and American Constitutional Democracy"

Dissertation Chair: Harvey C. Mansfield, Jr., Harvard University

The 1997 Leo Strauss Prize for the best dissertation in political theory is awarded to Andrew Sabl, Harvard University, for his dissertation, "Political Offices and American Constitutional Democracy."

In this dissertation, Sabl provides a theoretical account of three officesSenator, moral activist, and community organizer-to make a larger argument about the nature of political leadership in the United States. Rejecting both "utility" and "vocation" theories of leadership, Sabl draws on Aristotle and the Federalists to develop a pluralist account of the virtues and personalities appropriate to each office. All offices share the basic virtue of what Sabl calls "democratic continence," the exercise of leadership to restrain short-term popular impulses for the sake of long-term but nonetheless democratically-defined interests. In a series of case studies, Sabl brings these arguments to bear on the practice of leadership, showing how leaders have succeeded or failed to demonstrate democratic continence and the other particular virtues required by their office. The committee came away from reading the dissertation wishing to hear more; for example, about other offices and the argument's application to other polities. This is a bold and conceptually innovative work that raises new questions and prompts us to think about a familiar matter-the nature of political leadership-in a new way.

\section{Leonard D. White Award ( $\$ 500)$}

For the best doctoral dissertation completed and accepted in 1996 or 1997 in the field of public administration.

Award Committee: Clarence N. Stone, University of Maryland, chair; Lenneal Henderson, University of Baltimore; and Shui Yan Tang, University of Southern California

Recipient: Amy Beth Zegart, Stanford University

Dissertation: "In Whose Interest? The Making of American National Security Agencies"

\section{Dissertation Chair: Stephen Krasner, Stanford University}

The Leonard D. White Award this year goes to Amy Beth Zegart for her dissertation, "In Whose Interest? The Making of America's National Security Agencies." Based upon personal interviews and historical research, this dissertation examines the formation and evolution of the National Security Council, The Joint Chiefs of Staff, and the Central Intelligence Agency. These agencies of national security were all created in the 1940 s and were, in part, a response to what was then a new international environment and an evolving American role in that environment. Zegart shows, however, that the then-new agencies of national security were not simply responses to external events. They were largely shaped by an interplay between presidential actions and bureaucratic infighting, with Congress playing a very limited role both at the founding and during the evolution of these agencies. In contrast with agencies of domestic policy, interest groups are virtually nonplayers.

The initial enabling legislation proved to be especially important for all three agencies of national security, setting each on a unique trajectory of development. Zegart finds that structural decisions made when national security agencies are formed leave a lasting imprint in subsequent development and that, in subsequent development, these agencies are remarkably impervious to external events. Overall, the political forces that shape agencies of national security are radically different from those at work in the shaping of agencies of domestic policy, and Zegart suggests that agencies of international trade may represent yet another configuration.

What makes this dissertation extraordinary is not only the careful and detailed analysis of three agencies over half century of evolution, but its sophisticated use of theory drawn from diverse areas within the discipline. All of this is done with a keen eye fixed on issues of institutional design. As Zegart works through the implications of her research, she moves from her particular areas of concern to contribute to a broad theory of public bureaucracy.

In her conclusion, Zegart challenges academicians and policymakers alike "to find a useful, meaningful middle ground between grand theory and ad hoc reality." Because she herself has executed this task with exceptional skill, Zegart is a worthy model of how to conduct a first-rate analysis. "In Whose Interest?" displays both breadth of vision and depth of insight. It is a study that should be widely read and recognized for its genuine excellence. Its author appreciates the subtleties of politics and writes about them with clarity and grace.

\section{PAPER AND ARTICLE AWARDS}

\section{Pi Sigma Alpha/Franklin L. Burdette Award (\$500)}

For the best paper presented at the 1996 Annual Meeting.

Award Committee: Judith Stiehm, Florida International University, chair; T. David Mason, University of Memphis; and Joseph Zikmund II, State of Connecticut Department of Higher Learning

Recipient: Richard A. Brisbin, West Virginia University

Paper: "The U.S. Supreme Court and the Rationality of Labor Violence: The Impact of the Mackay Radio Doctrine and 
'Violence' during the Coal Strike of 1989-90"

The 1989-90 United Mine Workers of America strike against the Pittston Coal Group provides the setting for Richard A. Brisbin, Jr's paper. Written with a passion that is matched by voluminous documentation, this ambitious paper explores the impact on worker-management relations of a legalistic approach to labor policy, and why, under certain circumstances, workers choose extra-legal means to bargain with management. In particular, Brisbin focuses on law derived from NLRB v. Mackay Radio Telegraph (1938), the case which legalized the hiring of replacement workers. The paper analyses how management's use of tactics made legal by this case compelled workers to turn to extra-legal resistance which was considered "violence" by management.

In a complex discussion that applies game theory to a detailed case study, Brisbin argues that legalism and labor law combined to create a noncooperative bargaining game/process which provided an exit opportunity only for management. This asymmetry, in turn, contributed to the belief among workers that resistance, even "violent" civil disobedience, was rational. The paper then tackles the consequences of a legalism endorsed by both labor and management, which favored management, but which was appealed to even by labor after they first challenged it.

Brisbin urges more attention to the syudy of the impact of judicial decisions both on resistance and also on the economy of power and discipline embedded in legalism and law. The work is densely written, challenging, and thought-provoking.

\section{Heinz Eulau Prize $(\$ 500)$}

For the best article published in the American Political Science Review during 1996.

Award Committee: Kenneth A. Shepsle, Harvard University, chair, and Herbert Weisberg, Ohio State University

Recipients: James D. Fearon, University of Chicago and David D. Laitin, University of Chicago

Paper: "Explaining Interethnic Cooperation," 90(4): 715-35

It was the committee's view that any one of a half dozen papers might well have won this prize in a previous year, an accomplishment for which the past and present editors, G. Bingham Powell and Ada Finifter, and their respective editorial boards are to be congratulated. The committee, though feeling its mandate was to single out one paper for this prize, wishes to recognize "The Dynamics of Aggregate Partisanship" by Janet M. Box-Steffensmeier and Renee Smith, an article which displays a rare combination of substantive significance, theoretical intuition, and especially sophisticated methodological innovations. We can do no more than acknowledge the Box-Steffensmeier/Smith article as an exemplar of scientific research because it had the misfortune to be published in the same year as a remarkable paper by James D. Fearon and David D. Laitin.

The Heinz Eulau Prize for 1996 is awarded to Fearon and Laitin for their "Explaining Interethnic Cooperation." This paper is the product of two perfectly matched collaborators-one a widely recognized game theorist, the other an exemplary comparativist and student of group conflict and cooperation. The exceptional complementarities of these collaborators are exhibited in the present paper.

"Explaining Interethnic Cooperation" begins, in effect, by leveling a charge against the massive literature on ethnic politics, namely that this research is often guilty of sample selection bias. In seeking to explain ethnic conflict, this literature typically looks only at cases of ethnic conflict. In the words of the authors, "a good theory of ethnic conflict should be able to explain why, despite the greater tensions, peaceful and cooperative relations are by far the more typical outcome than large-scale violence." They construct a game-theoretic model that possesses intergroup cooperation as one of its equilibria. They further develop an interpretation about the social mechanisms that sustain such cooperation, an interpretation that places considerable emphasis on the role of intricate social networks within groups that serve to monitor, police, and punish violations by group members of cooperative expectations. Finally, they demonstrate, in their examination of another of the game's equilibria, that periods of peaceful intergroup interaction punctuated by occasional fits of intergroup violence are consistent with the model.

What distinguishes this paper, and in the final analysis what led the committee to award it this year's Eulau Prize, is that is displays social scientific reasoning at its most powerful and most cogent. It tackles a subject of consuming empirical interest and normative importance-intergroup relations; it embraces rather than ignores the complexity and variation accompanying such phenomena; it deploys highly sophisticated game-theoretic tools to explain and accommodate this complexity and variation; it provides interpretation and persuasive empirical instances that are laden with wisdom; and, in charting new research directions implied by this paper, it constitutes the beginning, not the conclusion, of a stimulating intellectual conversation. Along the way it shows how game theory can be freed from its more economic moorings to provide insights about politics, sociology, and psychology. In sum, "Explaining Interethnic Cooperation" is an agenda-setting piece of research, one that will stimulate a provocative research program. It is a paper that must be contended with by students of ethnicity and politics.

\section{BOOK AWARDS}

\section{Ralph J. Bunche Award (\$500)}

For the best scholarly work in political science published in 1996 which explores the phenomenon of ethnic and cultural pluralism.

Award Committee: Oliver Jones, Florida A\&M University, chair; Jeanne T. Meadows, Spelman College; and Franke Wilmer, Montana State University.

Recipients: Amy Gutmann, Princeton University and K. Anthony Appiah, Harvard University

Book: Color Conscious: The Political Morality of Race (Princeton University Press)

The 1997 Ralph J. Bunche Award committee is please to present its prize to Color Conscious: The Political Morality of Race by Amy Gutmann and Anthony Appiah. Color Conscious is a significant work which establishes the foundations for a serious and meaningful discourse on race, racism, identity, and public policy. It informs the discourse on race by providing a meaningful framework for analysis in the twenty-first century. The myriad issues that plague contemporary civic debates about how to come to terms with the cumulative effects of racial injustice are analyzed in a contextual framework that considers the ethical and structural changes necessary to redress the past and secure a pluralistic future of civic equality.

The authors remind us that public policy is not formulated in either a civic or moral vacuum, and courageously address the issue of racial injustice from the deeper level of ethics and philosophy. The result is an intellectually stimulating, methodologically meaningful, politically refreshing starting point for significant discourse for citizens and civic leaders alike. A very potent policy implication of 
the work, is the realization that, "in order to treat individuals fairly, the ultimate goal of a just society, it will sometimes be necessary to enact color conscious policies that recognize the extent to which race continues to influence the life chances of citizens."

\section{Gladys M. Kammerer Award $(\$ 1,000)$}

For the best political science publication in 1996 in the field of U.S. national policy.

Award Committee: Randy T. Simmons, Utah State University, chair; Edward G. Carmines, Indiana University; and Ruth Jones, Arizona State University

Recipient: Joel F. Handler, University of California, Los Angeles

Book: Down From Bureaucracy: The Ambiguity of Privatization and Empowerment (Princeton University Press)

Joel F. Handler analyzes decentralization, deregulation, and privatization with insight and passion. He cares deeply about decentralization's consequences for ordinary citizens. He asks, "Will ordinary citizens-clients, patients, teachers, students, parents, tenants, neighborshave more or fewer opportunities to exercise control over decisions that affect their lives?" The answer, he finds, depends on the circumstances and design of institutions.

In part because Handler recognizes that decentralization and privatization are manifestations of broader movements from the Right and Left that reject statism, he takes the topic seriously. The issue that concerns him is the struggle for power and he rightly understands that decentralization is about much more than finding the most efficient means of delivering a service. It is about the definition of values and "the arenas and procedures of conflict" and about "the reallocation of power and resources between various interest groups or stakeholders" as power and authority move to lower units of government or to the private sector.

Handler's analysis is enhanced by his understanding that what he calls "the social protection system" is based on the interaction of three large systems-government, the private sector (both forprofit and not-for-profit), and family. $\mathrm{He}$ examines that interaction and how it changes through decentralization, in a series of case studies on serious conflicts in American society-work and welfare, race, gender, family, bureaucracy, state and local power, and public education.

Because he examines his cases through the lens of citizen empowerment, the politics of decentralization play a large role in his analysis. The lessons, for proponents or opponents of decentralization, deregulation, or privatization are sobering as he describes how agencies maximize budgets, nomprofit organizations approximate state run bureaucracies, and private organizations seek favors and monopoly status. But, he says, poor outcomes are not foreordained. Indeed, his case studies provide lessons for how decentralization can be a positive step.

\section{Victoria Schuck Award (\$500)}

For the best book published in 1996 on women and politics.

Award Committee: Jane Mansbridge, Harvard University, chair; Nancy McGlen, Niagara University; and Shane Phelan, University of Hawai'i'

Recipient: Kristi Andersen, Syracuse University

Book: After Suffrage: Women in Partisan and Electoral Politics Before the New Deal (University of Chicago Press)

Kristi Andersen's After Suffrage argues persuasively that women's entrance into electoral politics in the United States contributed significantly to ending the high-turnout, highly partisan, favor-exchange-based, male bonding, torchlight parade form of politics that prevailed before the Progressive era, and instituting the non-partisan, candidate-centered, "citizen duty" approach to, say, voting that has deeply influenced the present. For good and ill (indeed, much of both), women thus helped spell the beginning of the end for traditional American political parties.

Women's formal entrance into politics also helped develop and further the "pressure group system" in contrast to the "party centered" system. American women might almost be said to have invented the public interest lobby. In the suffrage battle, women introduced what they called the "Front Door Lobby" (as opposed to "back door" private-interested lobbying), based on educating leaders and public opinion through expert testimony, public education campaigns, and grass-roots pressure engaged on ideal-regarding grounds. These techniques continued after suffrage in organizations like the League of Women Voters.

Andersen reveals instance after instance in which elite women's demands for representation on the strategy and other central committees of the Democratic and Republic parties were re- buffed. By excluding women, men preserved their own prerogatives. As Andersen joins her reporting of these setbacks with her point about nonpartisanship, we see that the men who controlled the parties were also preserving a "male model" of partisan politics that many women refused to join fully. They refused in part because of their convictions of their natural or socialized "difference" from men, and in part because the style that they had developed while out of power-based on cooperation, gathering information, and building consensus-fitted uneasily with male politics in what one woman party activist called the "battleground," populated with "gladiators" and "fighting animals."

Black women probably differed from White women in this regard, as Evelyn Brooks Higgenbotham, among others, has pointed out. Many Black women threw themselves eagerly into Republican Party politics, but found themselves soon replaced by men among the Black delegates to the party Convention, humiliated by racial slights and segregation within the party, and disillusioned by Hoover's racial and economic policies. The post 1928 shift to the Democratic Party did not provide many openings in local politics for Black women.

Yet Andersen points out that if we think of power as at least in part anticipatory (as one must), women's entry into electoral politics probably had far more impact than would appear simply by looking at women's roles in particular political decisions. Contrary to common wisdom, Andersen demonstrates that not only right after suffrage but for a long time to come a constellation of measures dealing with issues associated at the time with women's interests did pass in both state and federal legislatures. Indeed, Andersen argues, women's entrance into electoral politics preserved certain Progressive procedures and substantive goals (particularly those having to do with protective legislation for women and children, women's rights, consumer protection, and industrial health and safety, and increased governmental responsibility for the welfare of the vulnerable) into the New Deal through the interim period of redbaiting that undermined both the women's movement and other progressive movements.

Andersen's analysis of the changes in the American party system after suffrage raises the normative question of whether we can recapture the high involvement and high participation of the pre-suffrage model of political participation without its intolerance of non-party views, its corruption, its violence and "rowdyism," its rituals of male bonding, and its systematic exclusion of women. 
Honorable Mention: The Committee would like to extend an Honorable Mention to Roberta S. Sigel's work, Ambition and Accommodation: How Women View Gender Relations (University of Chicago Press, 1996) for its extraordinary contributions

\section{Woodrow Wilson Foundation Award $(\$ 5,000)$}

For the best book published in 1996 on government, politics, or international affairs.

Award Committee: John Mclver, University of Colorado-Boulder, chair; Sue E.S. Crawford, Creighton University; and Harvey Starr, University of South Carolina

Recipients: Jane Junn, Rutgers University, Norman Nie, University of Chicago, and Kenneth Stehlik-Barry, SPSS Inc.

Book: Education and Democratic Citizenship in America (University of Chicago Press)

\section{Education and Democratic Citizenship} in America addresses key political and policy issues, as well as central scholarly themes of political theory and political science inquiry. Given changes in the contemporary political world, as well as classic concerns in the study of politics, scholars in political theory, comparative politics, international relations, and public policy are attending to questions about the nature and development of democracy, and its meaning for governance and policy output. Within this context, Nie, Junn, and Stehlik-Barry do all scholars a service by clarifying the concept of citizenship-theoretically and empirically-investigating the nature of citizenship with a democracy.

Nie, Junn, and Stehlik-Barry argue clearly and persuasively that education is an important determinant of democratic citizenship, and that it has important (if different) effects on the two major dimensions of democratic citizenship: political engagement in pursuit of political interests and commitment to democratic values. By demonstrating how education can positively influence political tolerance (democratic enlightenment) while political participation (political engagement) is unaffected, the authors lead us to reconsider the character of education and the dynamics through which it alters both society and politics. The authors show that education affects citizenship through two paths: education improves cognition and education increases one's connections within social and political networks.

The two-path model uncovers com- plexity missing in previous theories linking education and citizenship. As education levels increase, there is no apparent logical restriction on increasing levels of commitment to democracy. Commitment to democracy is not competitive, either. One citizen's tolerance does not limit the ability of another citizen to be tolerant. A citizen in a nation of well educated citizens committed to democracy is even more likely to adopt a commitment to democracy. The number of connections to government institutions and elected officials, on the other hand, does have a limit. Increasing the level of education of the citizenry does not significantly ex pand the number of possible connections to political institutions. As a consequence, education need not automatically increase the participatory behavior and civic engagement of American citizens as prior work expects but empirical evidence denies.

Through creative research design Nie, Junn, and Stehlik-Barry translate their theoretical model into an empirical one, employing both times series and crosssectional approaches to analyze data on the cognition, behavior, and attitudes of Americans. Evidence supporting the model is initially drawn from cross-sectional analyses of the 1990 Citizen Participation Study. The model is then tested with longitudinal data from $\mathrm{Na}$ tional Election Studies and the General Social Survey. These longitudinal tests confirm that the two-path model explains patterns in education and citizenship attitudes and behaviors during the past quarter century in the United States. Exploratory analyses of comparative data from the 1990 International Social Survey Project suggest that the two-path model may also explain the effects of education on citizenship in other democratic and nondemocratic polities.

A theory of citizen participation that incorporates the two-path model is able to explain the puzzling lack of growth in political participation over time as education levels have increased. The twopath model also adds to our understanding of the effects of context on political attitudes and behavior. The theoretical advances in the book pave the way for new analysis of citizen commitment to democratic principles and citizen participation. The book also raises important implications for those who wish to improve citizen commitment to democracy or citizen participation. An education strategy appears to be effective for increasing average levels of tolerance and commitment to democracy. The evidence suggests that an increase in the level of citizen engagement, on the other hand, cannot be accomplished through education alone.
Ultimately, Education and Democratic Citizenship in America represents the very best of political science blending as it does intriguing theoretical analysis with a wide variety of types of evidence marshaled to explain a continuing empirical oddity of immense social and political importance. As an example of how our discipline can bring its unique perspectives to the analysis of public policies, this work serves as a suitable exemplar.

\section{CAREER AWARDS}

\section{Benjamin E. Lippincott Award $(\$ 1,500)$}

For a work of exceptional quality by a living political theorist that is still considered significant after a time span of at least 15 years since the original publication date.

Award Committee: Terrence Ball, University of Minnesota, chair; John Gunnell, State University of New York at Albany; and Alfonso Damico, University of Florida

Recipient: Hanna F. Pitkin, University of California-Berkeley

Book: The Concept of Representation (University of California Press, 1972)

Living as we do in a representative democracy it is imperative that we, not only as political scientists but as citizens and teachers of citizens, understand what it means to represent and to be represented. Hanna Fenichel Pitkin's The Concept of Representation clarifies and sometimes resolves the confusions and conundrums that attend this oft-contested concept. She shows how political representation resembles and differs from artistic, legal, literary, and other forms of representation. She offers incisive reconstructions and analyses of arguments advanced by Hobbes and Burke, amongst other theorists. She also constructs two ideal-typical theories of representation-the "mandate" and "independence" theories-and shows how many of our modern confusions stem from our failure to keep these distinct.

The Concept of Representation is, in short, a masterful analysis, blending both "historical" and "conceptual" approaches to political theory as a way of illustrating the darker recesses of modern political life. Three decades after its original publication, Pitkin's The Concept of Representation remains a model of how to do political theory, and a continuing source of scholarly and civic light. 


\section{John Gaus Award $(\$ 1,500)$}

The John Gaus Distinguished Lecturer Award honors the recipient's lifetime of exemplary scholarship in the joint tradition of political science and public administration and, more generally, recognizes and encourages scholarship in public administration.

Award Committee: H. George Frederickson, University of Kansas, chair; Susan J. Buck, University of North CarolinaGreensboro; and Louis Weschler, Arizona State University

Recipient: James G. March, Stanford University

The 1997 recipient of the John Gaus Award is James G. March, Professor of Political Science and Sociology Emeritus and Jack Steele Parker Professor of International Management Emeritus of Stanford University. James G. March was born in Cleveland, Ohio, in 1928 and is a Phi Beta Kappa graduate of the University of Wisconsin and holds graduate degrees from Yale University. He has received six honorary doctorates and is a Fellow of the National Academy of Education, the National Academy of Public Administration and the National Academy of Sciences. Among his many panel and committee memberships, he served as a Vice President of the American Political Science Association in 1983-84, and as an Editorial Associate of the American Political Science Review in 1957-58.

Professor March's best publications include Organizations (with Herbert A. Simon), A Behavioral Theory of the Firm (with Richard M. Cyert), Leadership and Ambiguity: The American College President (with Michael D. Cohen), Rediscovering Institutions: The Organizational Basis of Politics (with Johan P. Olsen), $A$ Primer on Decision Making: How Decisions Happen, and Democratic Governance (with Johan P. Olsen).

Professor March has published five books of poetry and is the only recipient of the Gaus Award to have been

knighted by King Harald as Knight First Class in the Royal Norwegian (Olav V) Order of Merit (1995).

In recent decades no one has done more than James G. March to combine political science and public administration. His work on institutions has significantly influenced both the discipline of political science and the field of public administration. Further, his recent work on decision making and on democratic governance represent important contributions to our understanding of government and administration. His scholarship is empirically informed and theoretically elegant and has stood the test of time.

\section{Hubert H. Humphrey Award (\$500)}

Presented each year in recognition of notable public service by a political scientist.

Award Committee: Gordon P. Whitaker, University of North Carolina, chair; Allen Settle, California Polytechnic State University-San Luis Obispo; Andrea Simpson, University of CaliforniaBerkeley

\section{Recipient: Paul D. Wellstone, United} States Senate

For Paul Wellstone, political science is an applied discipline, the study of politics directed toward public betterment. Throughout his career, Wellstone's scholarship, teaching, and political activism have informed and enriched each other, and his vision has been to help people-especially poor and disadvantaged people-build a stronger, more just community.

Wellstone has been at once a student and a practitioner of power and of empowerment. In How the Rural Poor Got Power, he wrote:

The point is that most reports and studies have not increased the power of the poor, and without a shift in the balance of power, policy and practice will remain the same; that prior to a "reordering of priorities" in America, there must be a reordering of power; that trying to reorder priorities without reordering power is a contradiction. It remains empty rhetoric unless strong and durable citizen organizations are developed to turn this appeal into specific programs backed by political clout. (1978)

That book is an analysis of community organizing in Minnesota that Wellstone helped lead to the early 1970's while he was a young professor of political science at Carleton College. Wellstone's interest in the study/teaching/practice of political action began during his student days at the University of North Carolina at Chapel Hill. His dissertation at UNC was written on community action organizing in Durham and he helped organize students and food service workers to improve working conditions on the Chapel Hill campus. During his twenty one years on the Carleton faculty, Wellstone continued to practice his own public-spirited brand of applied political science, eventually becoming a leader in Minnesota's Democratic-Labor party.

In 1990, Paul Wellstone was elected to the United States Senate from Minnesota. His was a grassroots campaign, waged from an old school bus in which he toured the state, and based on the enthusiastic support of thousands of volunteers. Wellstone won even though his opponent was the incumbent Senator and had seven times more money for the campaign.

Senator Wellstone has championed legislation to make government more responsive to the public at large and to improve people's quality of life. He has led efforts to reform political campaigning and lobbying, to protect the environment, to enhance the economic security of working people, to improve education, and to ensure access to health care. In his reelection campaign in 1996, he again defeated his much better-financed opponent through the mobilization of thousands and thousands of grassroots volunteers. This time, however, he was also able to run on his Senate record, basing his campaign on policy issues and delivering a consistent message: "Standing Up for Working Families and Children." Senator Wellstone's work in organizing and empowering people resulted not only in his own election, but also in nearly seventy percent of Minnesota voters turning out for the 1996 election.

Paul Wellstone, political scientist and public servant, and now U. S. Senator from Minnesota, is a particularly appropriate recipient of the Hubert $\mathbf{H}$. Humphrey Award for noteworthy public service. The American Political Science Association is honored to recognize his work with this award.

\section{Carey McWilliams Award (\$500)}

Presented each year to honor a major journalistic contribution to our understanding of politics.

Award Committee: W. Lance Bennett, University of Washington, chair; Holli A. Semetko, Syracuse University; and Kenneth Sherrill, Hunter College, CUNY

Recipient: Anthony Lewis, The New York Times

Anthony Lewis, the unanimous choice for the 1996-97 Carey McWilliams Award has educated several generations of political scientists on a wide range of topics, including constitutional law, civil rights, race relations, and international affairs. He has twice won the Pulitzer Prize, taught at a number of major universities, including Harvard and Columbia, and published books of enduring value for our understanding of politics. Among his works that continue to appear on political science reading lists 
are: Gideon's Trumpet, and Make No Law: The Sullivan Case and the First Amendment. His recent reports and essays on Bosnia reveal both his capacity to explain the politics of complex situations, and his gift for combining political analysis with moral reason.

\section{Charles E. Merriam Award (\$500)}

Given biannually to a person whose published work and career represents a significant contribution to the art of government through the application of social science research.

Award Committee: Michael Dean McGinnis, Indiana University, chair; Rodney Hero, University of Colorado; James Sheffield, Wichita State University

Recipient: Gary Orfield, Harvard University

The recipient of the 1997 APSA Merriam Award is Gary Orfield, Professor of Education and Social Policy at Harvard University. In his long and distinguished career, Orfield has effectively integrated research and service in the areas of civil rights, desegregation, educational policy, and urban politics. His research projects have resulted in many publications, but of particular relevance for his award is his long and diverse record of public service, as a witness in congressional hearings and court cases, as a court-appointed expert in school desegregation cases, and as a member of educational boards, commissions, and community agencies. $\mathrm{He}$ is a prominent authority on the interactions among educational practices, public policy, and employment opportunities for minority groups. It is clear that his advice is frequently sought by policymakers at all levels of American government, and that his policy recommendations are deeply informed by his many research projects. The Merriam Award Committee is very pleased to use this award to recognize Gary Orfield's outstanding record of research and public service.

\section{Frank J. Goodnow Award}

The APSA Council created the Frank J. Goodnow Award in 1996 to honor the outstanding contributions of individuals, groups and public and private organizations to both the development of the political science profession and the building of the American Political Science Association. The Goodnow award is named for Frank J. Goodnow, APSA's first president and an exemplar of the public service and volunteerism that this award represents.

\section{Recipients: \\ Eugene Eidenberg}

Teacher, author, politician, business executive: you contributed to the public weal as a professor, congressional aide, leader of your political party and corporate executive. Your career has ranged from the groves of academe at the Univesity of Minnesota to the halls of Congress as an APSA Congressional Fellow. Your prodigious talents served you well as Director of the Democratic National Committee, Secretary to the Cabinet, and later in the rough-and-tumble of free enterprise where you rose to Executive Vice President of the once upstart, now remarkably successful MCI Communications Corporation. Throughout all these activities, you remained grounded in intellectual values and public purposes.

With vision and foresight, you were instrumental in securing a multi-million dollar endowment grant from MCI to APSA's Congressional Fellowship Program, guaranteeing that future generations of political scientists and journalists will experience the unique opportunity that this program offers. It is with grateful acknowledgment of your lasting contribution to congressional scholarship, public journalism, and public service that we present to you the Frank J. Goodnow Award for distinguished service.

\section{Pendleton Herring}

Scholar, institution builder, foundation executive, advisor, collector: You have applied your wide-ranging intellect to building the social sciences, understanding democratic processes, and sustaining scholarly institutions. You led the Woodrow Wilson Foundation, sponsor of APSA's Woodrow Wilson Foundation Award, both as president and board member. As president of the Social Science Research Council for a remarkable twenty years, you advanced the quality, value, and effectiveness of interdisciplinary research in the social sciences. Your efforts helped build an infrastructure for the social sciences which demonstrated the social relevance of academic research. As consultant to the Bureau of the Budget and War Department, you served your country in a time of great need.

As executive associate of the Carnegie Foundation, you were instrumental in giving the Association its Washington presence. During your presidency of the American Political Science Association, the Congressional Fellowship Programnow in its 45 th year-was established. As a scholar, your seminal research contin- ues to influence the thinking and research agendas of new generations of political scientists. For the past half century you have donated political prints and engravings from your personal art collection to the Association. Every member and visitor to APSA's national headquarters can now appreciate the artistic depiction of democratic political life. In short, you have made the world of APSA a better place. It is with deep appreciation of your contributions to the institutional and scholarly life of political science that we present to you the Frank J. Goodnow Award.

\section{Roberta S. Sigel}

Scholar, mentor, pioneer, and institutional leader: Over the past half-century, you have made original scholarly contributions to the burgeoning field of women and politics, to the study of political socialization, and to interdisciplinary inquiries into psychology and politics. Rigor, insight and creativity mark your work. As a distinguished professor emeritus of political science at the State University of New Jersey, Rutgers, you have sustained your research productivity with your new volume, Ambition \& Politics: How Women View Gender Relations, published by the University of Chicago Press.

You are a beloved mentor of many students-men and women-who have themselves become leading scholars and teachers. You are a role model for a generation of women who will always remain in your debt for the example that you have set as a scholar and good citizen in the profession.

Your extensive service to the discipline has been marked by selflessness and conscientiousness. You have led the American Political Science Association as vice president and secretary and the International Society of Political Psychology as president. Less heralded are your additional thousands of hours of service to the profession, lending your time and judgment to scores of departmental, Association and disciplinary committees. Particularly significant for APSA, you helped establish the immensely successful Organized Sections, a structure that continues to infuse vitality into the discipline. It is with deep appreciation of your scholarship and distinguished service to your students, colleagues, and profession that we present to you the Frank J. Goodnow Award.

\section{Max M. Kampelman}

Diplomat, attorney, advisor, peacemaker, political scientist: Exemplifying the 
strong ties between political science and public service, you stand in our annals with such leaders as President Woodrow Wilson, British Ambassador to the United States Lord James Bryce, Vice President Hubert Humphrey, Ambassador Jeane Kirkpatrick, and Secretary of State Madeleine Albright. Doctoral graduate of the University of Minnesota, professor of political science at Bennington College and a director of Georgetown University and Mount Vernon College, your contributions to higher education have been extensive. At the same time, you have had a distinguished career in law and public service. Founder and senior partner of the law firm Fried, Frank, Harris, Shriver, and Kampelman, you led this partnership to national eminence. In the public sphere, you have served as trusted counsel to Senator Humphrey and as Counselor to the State Department. Committed to peace and human decency, you skillfully led the U.S. delegations to the Madrid EastWest Conference on Human Rights and the Geneva negotiations on Nuclear and Space Arms Reductions. We live in a safer world thanks to your vigorous efforts on behalf of humankind.

In the midst of these achievements, you have remained dedicated to the health of the American Political Science Association, serving for many years as its Treasurer and as a member of the Congressional Fellowship Program Advisory Board and the Kirkpatrick Fund Board. As a member of APSA's Council, you participated in the search for permanent headquarters for the Association and were instrumental in organizing the financing that made the undertaking possible. Often working behind the scenes, you have maintained a keen interest in the welfare of the Association. It is with deep gratitude for your many acts, large and small, on behalf of the nation and our scholarly society that we present to you the Frank J. Goodnow Award.

\section{APSA Publications List}

\footnotetext{
*Available from Customer Services Department, University Microfilms, 300 North Zeeb Road, Ann Arbor, Michigan 48106; phone, (800) 521-0600.
}

\section{PERIODICALS}

American Political Science Review. The leading quarterly journal for scholarly articles and book reviews in political science. Subscription cost is included in APSA membership. Back issues: $\$ 25$ per copy.

PS: Political Science and Politics. A quarterly journal of Association news and political analysis. $P S$ is the single best source for information on professional opportunities. Subscription cost is included in APSA membership. Back issues: $\$ 10$ per copy ( $\$ 15$ for June issue which includes a preliminary Annual Meeting program); $\$ 40$ per volume.

The Political Science Teacher. Stimulating quarterly magazine on education, curriculum, and teaching. Fall 1990 was the last separate issue of The Teacher. Beginning in with the March 1991 issue, The Teacher has been incorporated into PS.

\section{DIRECTORIES}

APSA Directory of Members, 1997-99 (1997). A triennial listing of the names, addresses, current positions, institutional affiliations, highest degrees, and fields of specialization of APSA individual members. Specialized indexes make it easy to locate political scientists by minority status, geographic location, and research interest. $\$ 50$, APSA members; $\$ 75$, nonmembers.

APSA Biographical Directory (1988). A complete listing of the names, addresses, current positions, institutional affiliations, highest degrees, fields of specialization, honors, and publications of APSA members. Specialized indexes make it easy to locate political scientists by minority status, geographic location, and research interest. $\$ 15$, APSA members; $\$ 20$, nonmembers.

Directory of Black Americans in Political Science (2nd ed., 1988). A listing of over 400 Black American political scientists that includes names, addresses, phone numbers, highest degrees, and fields of specialization. Indexed by fields of specialization and research interests. $\$ 5$.

Graduate Faculty and Programs in Political Science, 1995-97 (1995). A listing of over 300 Ph.D. and M.A. programs in political science in the United States and Canada. Each program description includes information about available specializations, tuition and financial aid, admissions data, enrollment statistics, degree requirements, degrees awarded, and lists of faculty along with each faculty member's name, highest degree, fields of specialization, and current position. The 1998-2000 Guide will be published in March 1998. \$20, APSA student members; $\$ 25$, regular members; $\$ 45$, nonmembers.

Directory of Undergraduate Political Science Faculty, 1996-98 (1996). A triennial listing of undergraduate, degreegranting departments of political science in the United States. Each department description includes addresses and phone numbers, and the names and specializations of member faculty. \$25, APSA members; $\$ 40$, nonmembers.

APSA Directory of Women of Color in Political Science (1997). A first-time, comprehensive listing of women of color in political science, which gives names, addresses, phone numbers, highest degrees, and fields of specialization.

APSA Directory of Political Science Departmental Chairpersons, 1997-98 (1997). Annual listing of the names and addresses of chairpersons of undergraduate political science degree-granting departments at four-year institutions. $\$ 20$, APSA members; $\$ 25$, nonmembers.

\section{INDEXES}

Cumulative Index to the American Political Science Review, 1906-68. $\$ 6.50^{*}$.

Cumulative Index to the American Political Science Review, 1969-95. Keyword index to all articles published in APSR between 1969 and 1995. \$25.

Cumulative Index to the Proceedings of the Annual Meeting. Keyword index to all papers included in the proceedings of the APSA Annual Meeting between 1904 and 1912 and 1956 and 1970. $\$ 18.50^{*}$

\section{SYLLABI COLLECTION}

The Political Science Course Syllabi Collection. The Course Syllabi Project compiles syllabi for reference and adaptation by departments, faculty, and teaching assistants designing courses. $\$ 10$ each, APSA members; $\$ 15$ each, nonmembers.

Introduction to International Relations (1991), edited by Linda Brady

American Government and Politics (1991), edited by Marjorie R. Hersey

Introduction to Political Theory (1992), edited by Peter G. Stillman

Introduction to Political Science (1992), edited by John C. Wahlke

Comparative Government and Politics (1991), edited by Frank L. Wilson

Public Law (1992), edited by Leif H. Carter

Methodology (1992), edited by John R. Freeman and W. Phillips Shively

Public Administration (1992), edited by Naomi Lynn

Political Behavior (1992), edited by Nancy H. Zingale

Women and Politics (1996), edited by Sally J. Kennedy

Capstone Course/Senior Seminar (1992), edited by Ronald Kahn. 